\title{
First results and interpretation of energy-flux measurements over Alpine permafrost
}

\author{
Catherine Mittaz, Martin Hoelzle, Wilfried Haeberli \\ Department of Geography, University of Zürich-Irchel, CH-8057 Zürich, Switzerland
}

\begin{abstract}
The interaction of energy-exchange processes between the atmosphere and the Earth surface determines the surface temperature regime. It is of fundamental importance to the question whether frozen ground exists at a given site and how rapidly it may decay in response to a climatic perturbation. To further our understanding of these processes, measurements concerning near-surface energy-exchange processes were initiated in January 1997 on creeping permafrost at a high mountain site, Murtèl-Corvatsch, upper Engadin, Swiss Alps. Data on all important energy-balance fluxes were collected. In this paper, we present groundtemperature and energy-balance measurements from Murtèl-Corvatsch for a 2 year period, 1997-99. We will examine the relative importance of the energy-balance components and discuss special problems relating to the coarse surface layer. The results indicate a non-zero energy budget, with a positive deviation of up to $78 \mathrm{~W} \mathrm{~m}^{-2}$ in winter and a negative deviation of up to $-130 \mathrm{~W} \mathrm{~m}^{-2}$ in summer. We propose that this overall imbalance of the energy-exchange fluxes, as well as the significant difference between mean annual surface and ground temperatures, can be explained by unmeasured advective energy fluxes that occur within the layer of large boulder blocks at the top of the permafrost.
\end{abstract}

\section{INTRODUCTION}

Together with glaciers, permafrost is one of the clearest climate indicators in the cryosphere. The sensitivity of the upper permafrost layers to decadal climatic changes, and the potential effect of permafrost degradation on natural hazards in high-Alpine environments, makes knowledge of the spatial distribution of mountain permafrost fundamentally important (Haeberli, 1992). Models permitting estimations of permafrost distribution patterns are especially useful for planning hazard-mitigation measures such as flood and avalanche protection, or any other construction activity (Keller and Hoelzle, 1996; Keller and others, 1998). Various efforts have been undertaken in recent years to develop and improve spatial modelling of mountain permafrost distribution based on empirical and statistical data, including digital elevation models, meteorological data and topological classification of microclimatic situations (Keller, 1992; Hoelzle and Haeberli, 1995; Hoelzle, 1996; Imhof, 1996; Etzelmüller and others, 1998). These empirical models have the advantage of needing very few input variables. However, they lack deeper process understanding. In addition, they strongly depend on regional characteristics and must be adapted to specific conditions in different areas such as Scandinavia, the Alps and the Sierra Nevada. Therefore, they are of limited use for spatial and temporal extrapolations.

A better understanding of both the processes of Alpine permafrost formation or decay and the distribution of discontinuous mountain permafrost requires a detailed knowledge of the energy-exchange processes at the atmosphere/lithosphere boundary. These processes determine the surface temperature regime (see Fig. 1) and are mainly controlled by climatic factors (solar radiation, clouds, etc.) and site-specific factors (aspect, slope, surface roughness, snow-cover thickness and duration, etc.) (Williams and Smith, 1989).

While measurements have been made in the Arctic (Weller and Holmgren, 1974; Smith, 1975; Ohmura, 1981; Hinkel and Outcalt, 1994; Outcalt and Hinkel, 1996), know-

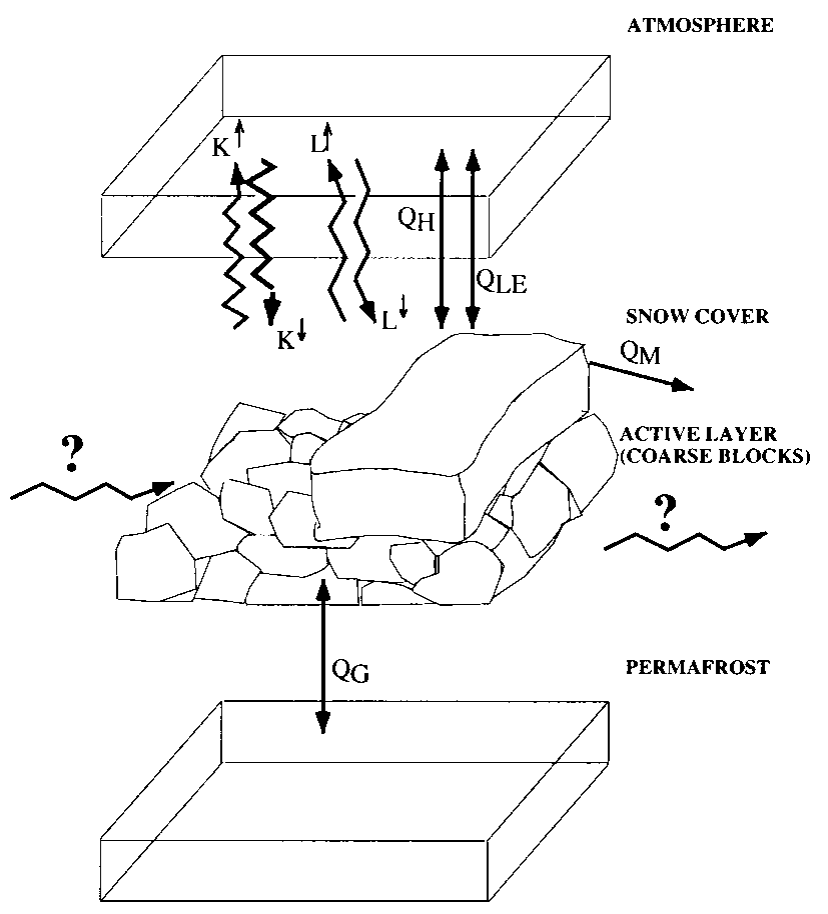

Fig. 1. Energy-exchange processes on a rock glacier. $K^{\downarrow}, K^{\uparrow}$, shortwave incoming and reflected radiation; $L^{\downarrow}, L^{\uparrow}$, longwave incoming and outgoing radiation; $Q_{\mathrm{H}}, Q_{\mathrm{LE}}$, sensible- and latent-heat flux; $Q_{\mathrm{M}}$, snowmelt energy; $Q_{\mathrm{G}}$, ground-heat flux. 


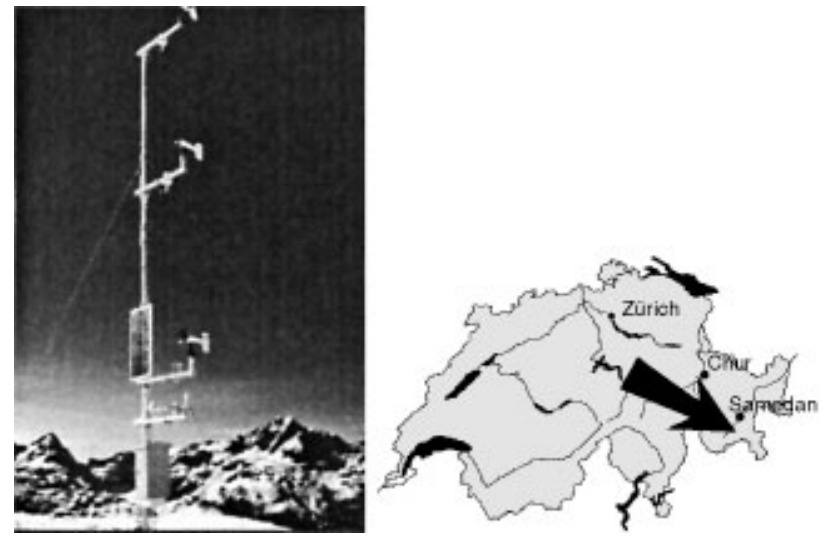

Fig. 2. Location of the energy-balance measurement station, Murtèl.

ledge of mass- and heat-exchange processes in Alpine permafrost environments is still severely limited. Only a few studies of the thermal regime within the active layer of Alpine permafrost exist (Humlum, 1997; Harris and Pedersen, 1998), mainly because of complications involving highly variable small-scale topography, extreme surface roughness, high porosity of the active layer and pronounced slope inclination. In order to assess the possibilities related to the collection, analysis, interpretation and application for spatial modelling of continuously recorded data, measurements concerning near-surface energy-exchange processes were initiated in January 1997 on creeping permafrost at a high mountain site, the Murtèl-Corvatsch rock glacier, upper Engadin, Switzerland. The site was chosen because ground temperatures have been measured in a $60 \mathrm{~m}$ deep borehole on this rock glacier since 1987. The present paper presents and discusses the first results and analyses of the data for a 2 year measurement period, 1997-99. It is hoped that evaluation of the most influential processes and parameters of the energy flux at the ground surface may later help to improve spatial modelling of permafrost occurrence and characteristics in rugged Alpine terrain.

\section{INVESTIGATION AREA}

The Murtèl-Corvatsch rock glacier is located northwest of the Murtèl cable-car station (cable car Surlej, Piz Corvatsch) within the ski area Silvaplana/Piz Corvatsch (Fig. 2). Facing north-northwest, the rock glacier is $2620-2850 \mathrm{~m}$ a.s.l. and about $400 \mathrm{~m}$ long and $200 \mathrm{~m}$ wide. The ogive-like transverse ridges are a consequence of compressive flow in the lower, less steeply inclined part. The surface consists of a layer of coarse boulder blocks (e.g. 1-3 m) and has only sparse vegetation.

A number of investigations have taken place on this rock glacier (e.g. Vonder Mühll, 1993; Hoelzle, 1994; Keller, 1994; Wagner, 1996; Kääb and others, 1998). In 1987, a 60 m deep core drilling was performed in the centre and at the transition from extending to compressive flow (Haeberli and others, 1988). The borehole is equipped with thermistors for longterm temperature monitoring. With an average temperature of about $-2{ }^{\circ} \mathrm{C}$ at $10 \mathrm{~m}$ depth and palaeoclimatic effects from past colder decades, total permafrost thickness is estimated to exceed $100 \mathrm{~m}$.

The structure of the rock glacier is as follows: Beneath a $3 \mathrm{~m}$ deep active layer consisting of blocky boulders, a layer with an extremely high ice content $(90-100 \%$ by volume) extends downward to $28 \mathrm{~m}$ depth. Beneath this layer, the rock glacier consists of coarse blocks with ice-filled pores (around $40 \%$ by volume; Haeberli and Vonder Mühll, 1996). Keller (1994) documented interactions between snow and permafrost through snow investigations (cf. Bernhard and others, 1998). Hoelzle (1994) modelled permafrost distribution in the Corvatsch-Furtschellas area utilizing BTS (bottom temperature of the snow cover) measurements and potential direct solar radiation calculations.

\section{METHODS: AUTOMATIC MICROMETEOROLOGI- GAL STATION}

The energy-balance measurement station at Murtèl was established in January 1997 with the aim of collecting information about all energy fluxes at this site. The micrometeorological station consists of a $10 \mathrm{~m}$ high tower with various meteorological sensors (see Table 1) and is located $5 \mathrm{~m}$ from the borehole (Mittaz, 1998). Air temperature, air humidity, wind speed and wind direction are measured at different heights (2, 6.50 and $9.10 \mathrm{~m}$ ). Snow height and longwave and shortwave incoming and outgoing radiation are measured $1.50 \mathrm{~m}$ above the surface. Data are recorded every $15 \mathrm{~s}$, averaged over a $30 \mathrm{~min}$ interval and transmitted by mobile phone to Zürich. Data collection started in January 1997 and is still in progress.

\section{RESULTS}

\section{Radiation}

All components of the radiation balance were measured directly. Shortwave incoming radiation reached daily values of

Table 1. Sensors and equipment of the micrometeorological station

\begin{tabular}{|c|c|c|c|}
\hline $\begin{array}{l}\text { Measured } \\
\text { variable }\end{array}$ & Equipment & Firm & Sensor \\
\hline $\begin{array}{l}\text { Logger/ } \\
\text { communica- } \\
\text { tion }\end{array}$ & $\begin{array}{l}\text { Data logger CR10X; } \\
\text { interval timer SDM-INT8; } \\
\text { multiplexer AM416; } \\
\text { PC card storage module; } \\
\text { solar panel }(50 \mathrm{~W}) \\
\text { Mobile phone communication }\end{array}$ & $\begin{array}{l}\text { Camp- } \\
\text { bell }\end{array}$ & \\
\hline $\begin{array}{l}\text { Radiation } \\
\text { (short- and } \\
\text { longwave) }\end{array}$ & Netradiometer CNR1 & $\begin{array}{l}\text { Kipp \& } \\
\text { Zonen }\end{array}$ & $\begin{array}{l}2 \text { pyranometer } \\
\text { CM3 } \\
2 \text { pyrgeometer } \\
\text { CG3 } \\
\text { Pt-100 temp. } \\
\text { sensor }\end{array}$ \\
\hline $\begin{array}{l}\text { Air temp. / } \\
\text { humidity }\end{array}$ & $\begin{array}{l}\text { Hygrometer } \\
\text { MP-100A ventilated }\end{array}$ & Rotronic & $\begin{array}{l}\text { RTD Pt-100 } \\
\text { Hygrometrs } \\
\text { C94 }\end{array}$ \\
\hline $\begin{array}{l}\text { Wind direc- } \\
\text { tion/ speed }\end{array}$ & Model 05103-5 & Young & Potentiometer \\
\hline Snow temp. & UTL1 & GIUB & TMG-1T \\
\hline $\begin{array}{l}\text { Soil tempera- } \\
\text { tures (bore } \\
\text { hole) }\end{array}$ & $\begin{array}{l}\text { YSI } 44006 \\
\text { UUB-31J1 }\end{array}$ & $\begin{array}{l}\text { Yellow } \\
\text { Springs } \\
\text { Instr. } \\
\text { Fenwal }\end{array}$ & NTG thermistor \\
\hline Snow height & SR50 & $\begin{array}{l}\text { Camp- } \\
\text { bell }\end{array}$ & $\begin{array}{l}\text { Ultrasonic } \\
\text { electrostatic } \\
\text { transducer }\end{array}$ \\
\hline
\end{tabular}


up to $430 \mathrm{~W} \mathrm{~m}^{-2}$ but strongly varied with daily and annual cycles (Fig. 3). Superimposed on these regular fluctuations were fluctuations with irregular frequencies such as cloudiness and changes in surface characteristics (e.g. albedo). During the entire measurement period, outgoing longwave radiation exceeded incoming longwave radiation by about $40-80 \mathrm{~W} \mathrm{~m}^{-2}$, reaching values of up to $390 \mathrm{~W} \mathrm{~m}^{-2}$ (Fig. 3). The ground experienced only slow temperature change, unlike the air, which was mixed more quickly by turbulence. Therefore, the temporal variation of longwave outgoing radiation was much smaller than the variation of incoming radiation.

Figure 4a compares air and surface temperature, the latter being calculated from longwave outgoing radiation by application of the Stefan-Boltzmann law. The emissivity of snow was set at $\varepsilon_{\mathrm{S}}=0.99$, and the emissivity of the ground material was set at $\varepsilon_{\mathrm{G}}=0.815$ (after Kondratyev, 1972; Keller, 1994).

The surface temperature increased strongly as soon as the snow cover disappeared at the end of June, and reached very high daily values (up to $30^{\circ} \mathrm{C}$ ). The highest measured surface temperature ( $30 \mathrm{~min}$ value) was $42.4^{\circ} \mathrm{C}$. The large boulders (e.g. $1-3 \mathrm{~m}$ ) on the surface of the permafrost also experienced very high temperatures during snowmelt, in May-June. Although most of the area was still covered with snow, the tops of some large block-shaped rocks were snow-free, causing the measured surface temperatures to be positive during this period (the pyrgeometer was installed at a height of $1.50 \mathrm{~m}$ with a $150^{\circ}$ field of view over an area of $5 \mathrm{~m}^{2}$ ). Figure $4 \mathrm{~b}$ shows some daily surface temperature values during this period.

\section{Turbulent fluxes}

Measured wind-speed profiles were seldom logarithmic as expected (Oke, 1987). In particular, when the surface was snow-covered, wind speed tended to decrease with increasing height. Cold air flowed downslope katabatically close to the
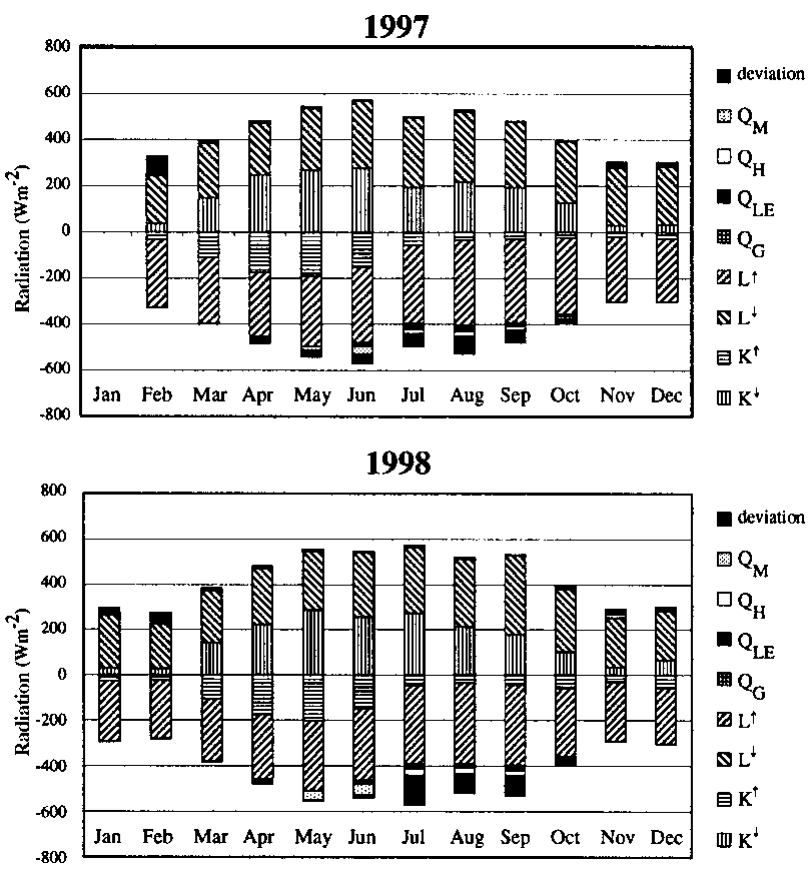

Fig. 3. Comparison of all energy-balance components for 1997 and 1998. $K^{\downarrow}, K^{\uparrow}$, shortwave incoming and reflected radiation; $L^{\downarrow}, L^{\uparrow}$, longwave incoming and outgoing radiation; $Q_{\mathrm{H}}, Q_{\mathrm{LE}}$, sensible- and latent-heat flux; $Q_{\mathrm{M}}$, snowmelt energy; $Q_{\mathrm{G}}$, ground-heat flux. surface, as on glaciers. Therefore turbulent fluxes were determined during winter using the bulk method, and not by the profile method:

$$
\begin{gathered}
Q_{\mathrm{H}}=-\rho c_{\mathrm{p}} k^{2} z_{u} z_{t}\left(\frac{\Delta u \Delta \theta}{\Delta z_{u} \Delta z_{t}}\right)\left(\phi_{\mathrm{m}} \phi_{x}\right)^{-1}, \\
Q_{\mathrm{LE}}=-\rho L_{\mathrm{v}} k^{2} z_{u} z_{q}\left(\frac{\Delta u \Delta q}{\Delta z_{u} \Delta z_{q}}\right)\left(\phi_{\mathrm{m}} \phi_{x}\right)^{-1},
\end{gathered}
$$

where $Q_{\mathrm{H}}$ and $Q_{\mathrm{LE}}$ are sensible- and latent-heat flux, respectively, $\rho$ is air density, $c_{\mathrm{p}}$ is specific heat of air, $k$ is von Kármán's constant, $L_{\mathrm{v}}$ is latent evaporation energy, $z_{u, t, q}$ is roughness length for wind speed, temperature and humidity, respectively, $\Delta \theta, \Delta u$ and $\Delta q$ are differences of potential temperature, wind speed and humidity, respectively, between measurement level and surface, $\phi_{\mathrm{m}, x}$ are Monin-Obukhov functions and $\Delta z$ is measurement level (Oke, 1987).

Measured wind speeds were always very low; the highest measured wind speed in 2 years was $12 \mathrm{~m} \mathrm{~s}^{-1}$. Therefore, the computed latent- and sensible-heat fluxes were small. The latent-heat flux had a monthly maximum in winter of $<10 \mathrm{~W} \mathrm{~m}^{-2}$ and a minimum in summer of $-50 \mathrm{~W} \mathrm{~m}^{-2}$. The maximum monthly sensible-heat flux in winter was $20 \mathrm{~W} \mathrm{~m}^{-2}$, and the minimum in summer was $-35 \mathrm{~W} \mathrm{~m}^{-2}$ (Fig. 3).

The surface roughness length for wind speed was derived from the measured wind profiles and was different during winter $(2 \mathrm{~cm})$ and summer $(14 \mathrm{~cm})$ due to the presence or absence of snow.
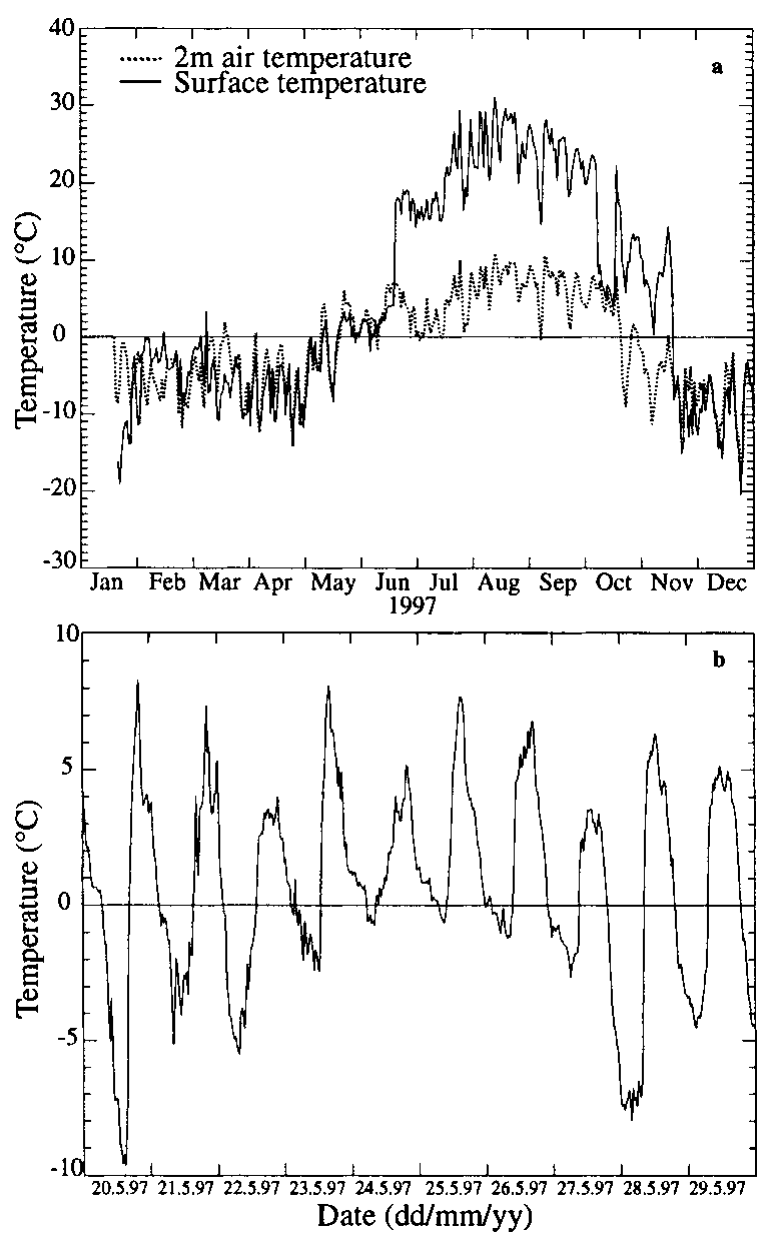

Fig.4. (a) Surface temperature and $2 m$ air temperature (daily values), 1997; (b) surface temperature during snowmelt period (daily values), 1997. 
Table 2. The calculated deviation $\left(\mathrm{Wm}^{-2}\right)$ from the zero energy balance for different seasons

\begin{tabular}{lcc}
\hline \multicolumn{1}{c}{ Season } & 1997 & 1998 \\
\hline January-March & -31 & -21 \\
April-October & 38 & 47 \\
November-December & -16 & -13 \\
\hline
\end{tabular}

\section{Ground-heat flux}

The ground-heat flux was calculated as pure heat conduction:

$$
Q_{\mathrm{G}}=k \frac{\mathrm{d} T}{\mathrm{~d} z},
$$

where $Q_{\mathrm{G}}$ is ground-heat flux, $k$ is thermal conductivity of the ground and $\mathrm{d} T / \mathrm{d} z$ is temperature gradient in the ground.

The temperature gradient was determined with the thermistors at depths of 0.6 and $3.6 \mathrm{~m}$. A value of 2.49 for the thermal conductivity of the blocks was taken from Vonder Mühll (1988). The ground-heat flux stayed negative and small, $-3 \mathrm{~W} \mathrm{~m}^{-2}$, during winter, but became positive in May when meltwater started penetrating into the still frozen active layer (Fig. 3). These measurements confirm results obtained by Keller and Gubler (1993) in the same region. During the snow-free period, ground-heat fluxes of up to $+28 \mathrm{~W} \mathrm{~m}^{-2}$ were obtained. The insulating effect of the snow cover is obvious and has been described by several authors (e.g. Goodrich, 1982).

\section{Heat flux through the snow cover}

Like ground-heat flux, heat flux through the snow cover was calculated as pure heat conduction. To obtain a temperature gradient, the temperatures at the snow surface and at the bottom of the snow cover were measured using minature dataloggers (Hoelzle and others, 1999). These were installed as recently as autumn 1997, so heat flux through the snow cover for winter and spring 1997 was calculated based on borehole tem- peratures ( $0.6 \mathrm{~m}$ thermistor) and temperatures at the snow surface (pyrgeometer). Thermal conductivity is a function of the snow density (after Mellor, 1977; Keller, 1994). The density of the snow cover was assumed to be the same as in winter 1990/ 91 when it was measured by Keller (1994), since both winters had a relatively large snow accumulation of up to $2 \mathrm{~m}$. The calculated heat fluxes varied between -1.5 and $2 \mathrm{~W} \mathrm{~m}^{-2}$, reflecting the insulating effect of the snow cover (Fig. 3).

\section{Snowmelt energy}

Latent melt energy was determined as a function of snow height and snow density. The measured minimum daily peaks reached $-90 \mathrm{~W} \mathrm{~m}^{-2}$, but affected the energy balance only during the melting period (Fig. 3).

\section{Gomparison of individual components}

The results obtained during 1997 and 1998 are shown as monthly means in Figure 3. The radiation components are the dominant factors. Ground-heat flux, latent melt energy (during the snowmelt season) and turbulent fluxes during summer all vary within the same order of magnitude, but are much smaller than the radiation fluxes. Heat flux through the snow cover is too small to be included in this plot.

The sum of all measured components of the energy balance is also plotted in Figure 3. If all energy-balance components are determined correctly their sum should theoretically be zero. The calculated deviation from this theoretical case is negative during winter (minimum monthly value $-78 \mathrm{~W} \mathrm{~m}^{-2}$ (February 1997)) and positive during summer (maximum monthly value $130 \mathrm{~W} \mathrm{~m}^{-2}$ (July 1998)). The mean differences are given in Table 2.

\section{DISGUSSION AND CONGLUSIONS}

Compared with other energy-balance data (Table 3), the data collected at Murtèl seem to be quite reasonable. Nevertheless, the deviation between a zero energy balance and the calculated sum of the energy-balance components averaged over 1 year is $15 \mathrm{~W} \mathrm{~m}^{-2}$ for 1997 and $24 \mathrm{~W} \mathrm{~m}^{-2}$ for 1998; it

Table 3. Compilation of energy-balance data at arctic and alpine sites in $\mathrm{Wm}^{-2}$

\begin{tabular}{|c|c|c|c|c|c|c|c|c|c|c|c|}
\hline Date & $L^{\downarrow}$ & $L^{\uparrow}$ & $K^{\downarrow}$ & $K^{\uparrow}$ & $Q_{\mathrm{H}}$ & $Q_{\mathrm{LE}}$ & $Q_{\mathrm{G}}$ & Surface & Location & $\begin{array}{l}\text { Altitude } \\
\text { ma.s.l. }\end{array}$ & Source \\
\hline Iarch 1997 & 236 & -205 & 37 & -31 & 10.00 & 2 & -1 & Coarse blocks & Murtèl-Corvatsch & 2700 & This study \\
\hline pril 1997 & 226 & -279 & 247 & -174 & 9.00 & 2 & -1 & Coarse blocks & Murtèl-Corvatsch & 2700 & This study \\
\hline ay 1997 & 267 & -304 & 266 & -192 & 7.00 & 3 & 1 & Coarse blocks & Murtèl-Corvatsch & 2700 & This study \\
\hline ne 1997 & 294 & -325 & 276 & -155 & -6.00 & -9 & 1 & Coarse blocks & Murtèl-Corvatsch & 2700 & This study \\
\hline uly 1997 & 303 & -337 & 193 & -58 & -18.00 & -27 & 4 & Coarse blocks & Murtèl-Corvatsch & 2700 & This study \\
\hline lugust 1997 & 305 & -369 & 218 & -34 & -17.00 & -31 & 7 & Coarse blocks & Murtèl-Corvatsch & 2700 & This study \\
\hline 0-31 March 1993 & 241 & -277 & 197 & -168 & -5.70 & -0.6 & & Snow & Weissfluhjoch, Swiss Alps & 2540 & Plüss (1997) \\
\hline April 1993 & 259 & -296 & 232 & -188 & -3.00 & -1.2 & & Snow & Weissfluhjoch, Swiss Alps & 2540 & Plüss (1997) \\
\hline May 1993 & 281 & -311 & 252 & -175 & -0.00 & -0.4 & & Snow & Weissfluhjoch, Swiss Alps & 2540 & Plüss (1997) \\
\hline June 1993 & 292 & -313 & 220 & -140 & 1.60 & 0.2 & & Snow & Weissfluhjoch, Swiss Alps & 2540 & Plüss (1997) \\
\hline July 1973 & & & 144 & & -72.00 & -55 & -17 & Alpine tundra & Niwot Ridge, Colorado, U.S.A. & & LeDrew and Weller (1978) \\
\hline July 1971 & & & 115 & & -37.00 & -76 & -2 & Arctic tundra & Barrow, Alaska, U.S.A. & & LeDrew and Weller (1978) \\
\hline July 1985 & 243 & -349 & 301 & -54 & -73.00 & -59 & & Tundra & Plateau Mountain, Alberta, Canada & 2475 & Ohmura and others (1991) \\
\hline 19 July 1983 & 288 & -371 & 276 & -65 & -41.00 & -79 & & Alpine meadow & Gletsch, Swiss Alps & 1765 & Bernath (1991) \\
\hline 16 August 1983 & 303 & -342 & 166 & -38 & -25.00 & -66 & & Alpine meadow & Gletsch, Swiss Alps & 1765 & Bernath (1991) \\
\hline
\end{tabular}

Notes: $K^{\downarrow}, K^{\uparrow}$, shortwave incoming and reflected radiation; $L^{\downarrow}, L^{\uparrow}$, longwave incoming and outgoing radiation; $Q_{\mathrm{H}}, Q_{\mathrm{LE}}$, sensible- and latent-heat flux; $Q_{\mathrm{M}}$, snowmelt energy; $Q_{\mathrm{G}}$, ground-heat flux. 


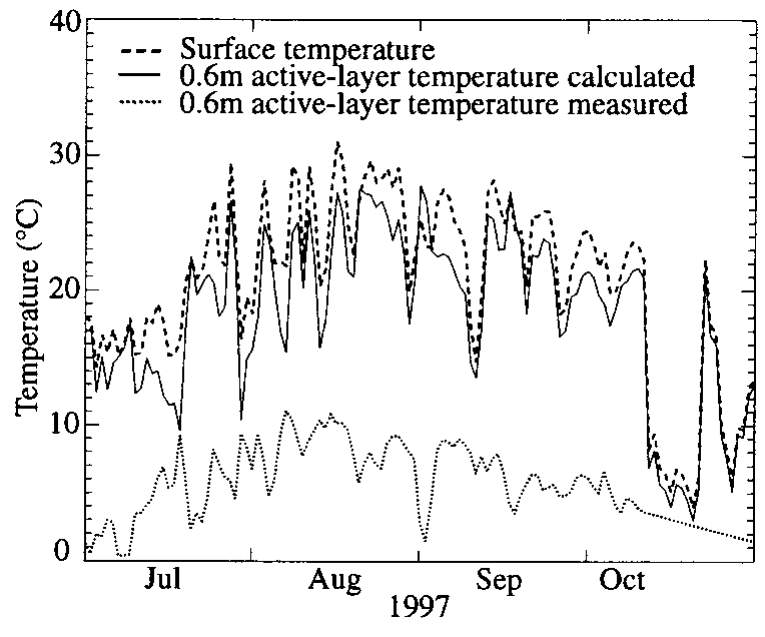

Fig. 5. Measured and calculated $0.6 \mathrm{~m}$ active-layer temperature (daily values).

amounts to more than half the radiation-balance values (28 $\mathrm{W} \mathrm{m}^{-2}$ for 1997; $33 \mathrm{~W} \mathrm{~m}^{-2}$ for 1998).

The most probable reason for the surplus/lack of energy in this study is the unmeasured energy flux from lateral advection within the active layer. A system of vertical funnels appearing within the snow cover on the rock glacier in early winter is a clear indicator of such a lateral energy flux within the layer of coarse boulder blocks (Bernhard and others, 1998).

The mean annual ground-surface temperature was determined as the average of the $0.6 \mathrm{~m}$ borehole temperature (1997), the minature datalogger temperature (1997/98) during winter and the surface temperature calculated from longwave radiation for summer. Mean annual ground-surface temperature reached maximum values of $5.9^{\circ} \mathrm{C}$ in 1997 and $5.0^{\circ} \mathrm{C}$ in 1998 . Such high mean annual surface-temperature values at the top of perennially frozen ground clearly indicate that heat conduction is not the only energy-exchange process within the underlying active layer. Important advective fluxes of energy within the coarse boulder blocks surrounded by air must contribute to the difference between surface and ground temperature. In fact, a $0.6 \mathrm{~m}$ active-layer temperature calculated from mean ground-surface temperature and heat conduction differs from the measured $0.6 \mathrm{~m}$ borehole temperature by between $-10^{\circ} \mathrm{C}$ during winter and $+25^{\circ} \mathrm{C}$ in summer (1997) (see Fig. 5).

These differences may be due to unmeasured advective heat fluxes within the blocky surface layer. The difference can provide an estimate of the unmeasured advective heat flux: we calculated mean seasonal advective fluxes of $+5 \mathrm{~W} \mathrm{~m}^{-2}$ during winter and $-26 \mathrm{~W} \mathrm{~m}^{-2}$ in summer. Although the processes causing such advection - and the accuracy of the values - are unknown, we propose that these numbers represent order-of-magnitude estimates of summer and winter advective heat fluxes and may account for the observed energy imbalance.

\section{PERSPEGTIVES}

A realistic consideration of the advective energy flux in the active layer seems to be a fundamental precondition for linking near-surface temperatures to thermal conditions at depth (permafrost temperature and thickness). As a further step in the measurement program, a few small (1-2 m) boreholes will be drilled into some of the boulder blocks of the active layer. Data of the temperature profile within the blocks will then be obtained and should help characterize the advective energy flux within the active layer.

With a better knowledge of the energy-exchange processes at the atmosphere/lithosphere boundary, our understanding of Alpine permafrost formation, decay and distribution may be improved, as these processes determine the surface temperature regime. A complete understanding of the energyexchange processes involved would open the way towards realistic parameterizations and spatial modelling of the essential energy fluxes by using meteorological data as input. However, the scientific and technical difficulties induced by the specific characteristics of Alpine permafrost surfaces cause a number of problems to be solved and make half-empirical approaches most promising in the near future. Potentially, the most important step at this time is to further develop documentation and quantification of the complex processes within the active layer.

\section{ACKNOWLEDGEMENTS}

We would like to thank the cable-car company Surlej-Corvatsch, and many colleagues for help in the field. We are indebted to the referees and E. Lutz for their careful suggestions that improved the clarity of the paper. This work was funded by the Federal Office for Education and Sciences (contract 97.0054-2) within the European Union programme "Permafrost and Climate in Europe" (PACE; contract ENV4-CT97-0492).

\section{REFERENGES}

Bernath, A. 1991. Zum Wasserhaushalt im Einzugsgebiet der Rhône bis Gletsch. Untersuchungen zu Niederschlag, Verdunstung und Abfluss in einem teilweise vergletscherten Einzugsgebiet. Zürcher Geogr. Schr. 43.

Bernhard, L., F. Sutter, W. Haeberli and F. Keller. 1998. Processes of snow permafrost-interactions at a high-mountain site, Murtèl/Corvatsch, eastern Swiss Alps. Université Laval. Centre d'Études Nordiques. Collection Nordicana $57,35-41$.

Etzelmüller, B., I. Berthling and J. L. Sollid. 1998. The distribution of permafrost in southern Norway - a GIS approach. Université Laval. Centre d'Études Nordiques. Collection Nordicana 57, 251-258.

Goodrich, L. E. 1982. The influence of snow cover on the ground thermal regime. Can. Geotech. J., 19(4), 421-432.

Haeberli, W. 1992. Construction, environmental problems and natural hazards in periglacial mountain belts. Permafrost and Periglacial Processes, 3(2), 111-124.

Haeberli,W. and D. Vonder Mühll. 1996. On the characteristics and possible origins of ice in rock glacier permafrost. Z. Geomorphol., Supplementband 104, 43-57.

Haeberli, W., J. Huder, H.-R. Keusen, J. Pika and H. Röthlisberger. 1988. Core drilling through rock glacier-permafrost. In Senneset, K., ed. Permafrost. Fifth International Conference. Proceedings. Vol. 2. August 2-5, 1988. Trondheim, Tapir Publishers, 937-942.

Harris, S. A. and D. E. Pedersen. 1998. Thermal regimes beneath coarse blocky materials. Permafrost and Periglacial Processes, 9(2), 107-120.

Hinkel, K. M. and S. I. Outcalt. 1994. Identification of heat-transfer processes during soil cooling, freezing, and thaw in central Alaska. Perma frost and Periglacial Processes, 5 (4), 217-235.

Hoelzle, M. 1994. Permafrost und Gletscher im Oberengadin. Grundlagen und Anwendungsbeispiele für automatisierte Schätzverfahren. Eidg. Tech. Hochschule, Zürich.Versuchsanst.Wasserbau, Hydrol. Glaziol. Mitt. 132.

Hoelzle, M. 1996. Mapping and modelling of mountain permafrost distribution in the Alps. Nor. Geogr. Tidsskr, 50 (1), 11-15.

Hoelzle, M. and W. Haeberli. 1995. Simulating the effects of mean annual air-temperature changes on permafrost distribution and glacier size: an example from the Upper Engadin, Swiss Alps. Ann. Glaciol., 21, 399-405.

Hoelzle, M., M. Wegmann and B. Krummenacher. 1999. Minature dataloggers for mapping and monitoring of permafrost in high mountain areas: first experience from the Swiss Alps. Permafrost and Periglacial Processes, 10(2), 113-124.

Humlum, O. 1997. Active layer thermal regime at three rock glaciers in 
Greenland. Permafrost and Periglacial Processes, 8(4), 383-408.

Imhof, M. 1996. Modelling and verification of the permafrost distribution in the Bernese Alps (western Switzerland). Permafrost and Periglacial Processes, 7(3), 267-280.

Kääb, A., G. H. Gudmundsson and M. Hoelzle. 1998. Surface deformation of creeping mountain permafrost. Photogrammetric investigations on rock glacier Murtèl, Swiss Alps. Université Laval. Centre d'Études Nordiques. Collection Nordicana 57, 531-537.

Keller, F. 1992. Automated mapping of mountain permafrost using the program PERMAKART within the geographical information system ARC/INFO. Permafrost and Periglacial Processes, 3(2), 133-138.

Keller, F. 1994. Interaktionen zwischen Schnee und Permafrost: eine Grundlagenstudie im Oberengadin. Eidg. Tech. Hochschule, Zürich. Versuchsanst.Wasserbau, Hydrol. Glaziol. Mitt. 127.

Keller, F. and H. Gubler. 1993. Interaction between snow cover and high mountain permafrost, Murtèl-Corvatsch, Swiss Alps. In Cheng Guodong, ed. Permafrost. Sixth International Conference. Proceedings, Vol. 1. July 5-9 1993, Beijing, China. Guangzhou, South China University of Technology Press, 332-337.

Keller, F. and M. Hoelzle. 1996. PERMAKART und PERMAMAP. In Haeberli, W. and M. Hoelzle, eds. Simulation der Permafrostverbreitung in den Alpen mit geographischen Informationssystemen. Zürich, vdf Hochschulverlag an der ETH Zürich, 36-46.

Keller, F. and 8 others. 1998. Permafrost map of Switzerland. Université Laval. Centre d'Etudes Nordiques. Collection Nordicana 57, 557-562

Kondratyev, K. Ya. 1972. Radiation processes in the atmosphere. Geneva, World Meteorological Organization. (WMO TD 309.$)$

LeDrew, E. F. and G. Weller. 1978. A comparison of the radiation and energy balance during the growing season for an Arctic and Alpine tundra. Arct. Alp. Res., 10(4), 665-678.

Mellor, M. 1977. Engineering properties of snow. f. Glaciol., 19(81), 15-66.
Mittaz, G. 1998. Energiebilanz über alpinem Permafrost. Eidg. Tech. Hochschule, Zürich.Versuchsanst. Wasserbau, Hydrol. Glaziol. Mitt. 158, 152-167.

Ohmura, A. 1981. Climate and energy balance on Arctic tundra, Axel Heiberg Island, Canadian Arctic Archipelago, spring and summer 1969, 1970 and 1972. Zürcher Geogr. Schr. 3.

Ohmura, A., H. Gilgen and M. Wild. 1991. Global Energy Balance Archive GEBA. Zürcher Geogr. Schr. 44.

Oke, T. R. 1987. Boundary layer climates. Second edition. London, Methuen; New York, Routledge Press.

Outcalt, S. I. and K. M. Hinkel. 1996. The response of near-surface permafrost to seasonal regime transitions in tundra terrain. Arct. Alp. Res., 28(3), 274-283.

Plüss, C. 1997. The energy balance over an Alpine snowcover. Zürcher Geogr. Schr. 65.

Smith, M.W. 1975. Microclimatic influences on ground temperatures and permafrost distribution, Mackenzie Delta, Northwest Territories. Can. 7. Earth Sci., 12(8), 1421-1438.

Vonder Mühll, D. 1988. Geothermische Studien zur Permafrost-Bohrung Murtèl-Corvatsch. (Diplomarbeit, Eidgenössische Technische Hochschule, Zürich, Switzerland.)

Vonder Mühll, D. S. 1993. Geophysikalische Untersuchungen im Permafrost des Oberengadins. Eidg. Tech. Hochschule, Zürich. Versuchsanst. Wasserbau, Hydrol. Glaziol. Mitt. 122.

Wagner, S. 1996. Dreidimensionale Modellierung zweier Gletscher und Deformationsanalyse von eisreichem Permafrost. Eidg. Tech. Hochschule, Zürich.Versuchsanst.Wasserbau, Hydrol. Glaziol. Mitt. 146.

Weller, G. and B. Holmgren. 1974. The microclimates of the Arctic tundra. 7. Appl. Meteorol., 13(8), 854-862.

Williams, P.J. and M.W. Smith. 1989. The frozen earth: fundamentals of geocryology. Cambridge, Cambridge University Press. 